J Neurol (1983) 230:193-196

\title{
Plasma arginine vasopressin concentrations in epileptics under monotherapy
}

\author{
K.-H.Krause ${ }^{1}$, W. Rascher ${ }^{2}$, and P. Berlit ${ }^{1}$ \\ ${ }^{1}$ Neurological Clinic and \\ ${ }^{2}$ Department of Pharmacology, University of Heidelberg, D-6900 Heidelberg, \\ Federal Republic of Germany
}

Summary. Plasma arginine vasopressin concentrations were determined by radio-immunoassay in 112 adult epileptics who were taking carbamazepine, phenytoin, primidone, or sodium valproate in long-term monotherapy, and in 19 controls. No significant difference was found between the groups, but some epileptics taking carbamazepine and primidone showed low values. Serum concentrations of carbamazepine did not correlate with the concentrations of plasma arginine vasopressin. In conclusion, there was no evidence of a stimulating effect of chronic carbamazepine medication or a special inhibiting effect of phenytoin on the release of vasopressin arginine from the posterior pituitary.

Key words: Arginine vasopressin - Carbamazepine - Anticonvulsants Epilepsy

Zusammenfassung. Bei 112 unter Monotherapie mit Carbamazepin, Phenytoin, Primidon oder Valproat stehenden erwachsenen Anfallskranken sowie bei 19 gleichaltrigen Kontrollpersonen wurden radioimmunologisch die Vasopressin-Plasma-Konzentrationen bestimmt. Es wurden keine signifikanten Unterschiede zwischen den Gruppen gefunden. Einige der mit Carbamazepin und Primidon monotherapierten Epileptiker wiesen niedrige Vasopressin-Werte auf. Die Carbamazepin-Serumspiegel korrelierten nicht mit den Vasopressin-Konzentrationen. Somit ergab sich weder ein Hinweis auf eine vermehrte Vasopressin-Ausschüttung unter Langzeittherapie mit Carbamazepin noch eine besondere Hemmung der Ausschüttung durch Phenytoin.

Different influences on diuresis have been reported for carbamazepine and phenytoin. While carbamazepine has been shown to have an antidiuretic effect $[1,4,6,7,9,11,12]$, phenytoin can reverse carbamazepine-induced water intoxication [10] and interferes (when given in high intravenous doses) with the release of

Offprint requests to: Dr. K.-H. Krause, Neurologische Universitätsklinik, Voss-Strasse 2, D-6900 Heidelberg, FRG 


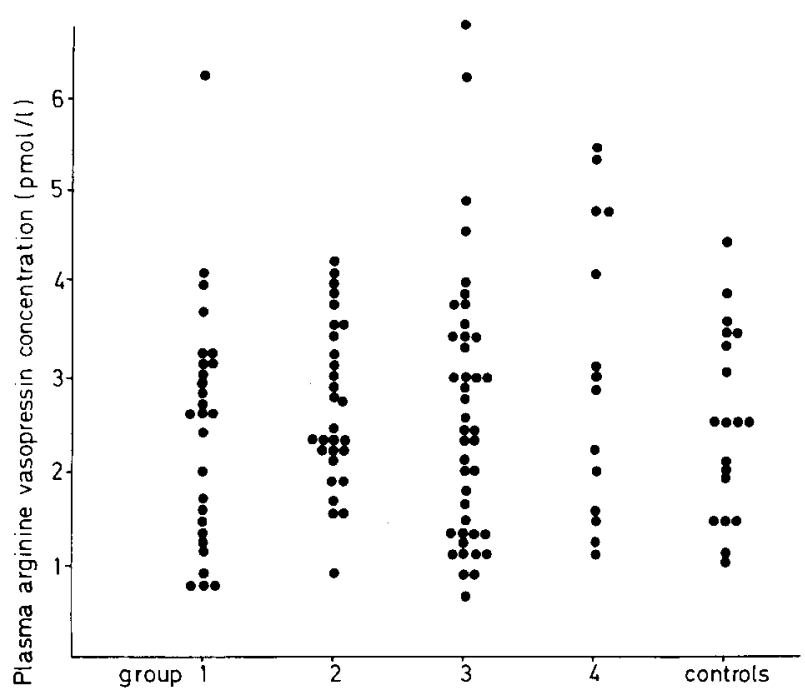

Fig. 1. Plasma arginine vasopressin concentrations in epileptics under long-term monotherapy with anticonvulsants (group 1, carbamazepine; group 2, phenytoin; group 3, primidone; group 4 , valproate sodium) and in controls

arginine vasopressin [2]. It has been suggested that carbamazepine exerts its antidiuretic effect by stimulating the release of antidiuretic hormone from the posterior pituitary $[1,4,9]$, but this could not be confirmed by others [3,11]. Thus, the effect of carbamazepine on plasma antidiuretic hormone concentration remains uncertain $[5,13]$. The aim of the present study was to investigate the influence of different anticonvulsants on the plasma arginine vasopressin concentrations in adult epileptic patients receiving long-term monotherapy with carbamazepine, phenytoin, primidone and valproate sodium.

\section{Patients and methods}

Plasma arginine vasopressin concentrations were determined using a sensitive and specific radio-immunoassay [8]. Measurements were carried out in the plasma of 112 adult epileptics aged 20-40 years, receiving anticonvulsant monotherapy for at least 1 year, and of 19 controls of the same age; 27 patients were taking carbamazepine (group 1), 29 phenytoin (group 2), 42 primidone (group 3), and 14 sodium valproate (group 4). Levels of anticonvulsants in serum were determined by the enzyme multiplied immunoassay technique. Plasma sodium was determined by flame photometry. The significance of differences between the groups was assessed by analysis of variance, the correlation of plasma arginine vasopressin concentrations and carbamazepine levels in serum was performed by linear regression analysis.

\section{Results}

The mean plasma arginine vasopressin concentration of the four groups of epileptics and of the controls did not differ significantly (mean \pm SD in group 1 , $1.96 \pm 0.97 \mathrm{pmol} / 1$; group $2,2.22 \pm 0.71$; group 3, $2.15 \pm 1.15$; group $4,2.51 \pm 1.28$ 
and in controls $2.59 \pm 0.96$ ). As shown in Fig. 1, vasopressin levels tended to be lower in some patients on carbamazepine and primidone. The serum concentrations of the anticonvulsants were within the therapeutic range in all epileptics (mean \pm SD for carbamazepine $8.2 \pm 2.4 \mu \mathrm{g} / \mathrm{ml}$, for phenytoin $8.6 \pm 5.8 \mu \mathrm{g} / \mathrm{ml}$, for primidone $12.0 \pm 5.2 \mu \mathrm{g} / \mathrm{ml}$, and for sodium valproate $66.4 \pm 23.4 \mu \mathrm{g} / \mathrm{ml}$ ). There was no significant correlation between the concentrations of plasma arginine vasopressin and carbamazepine (correlation coefficient $r=-0.151$, $P>0.05$ ). No patient showed clinical signs of water intoxication; plasma sodium concentrations were within the normal range in all epileptics (mean $\pm S D$ in group 1, 140.3 \pm 2.8 ; group 2, 140.4 \pm 1.2 ; group 3, 140.4 \pm 2.3 ; group 4, $140.2 \pm 2.0$ $\mathrm{mmol} / \mathrm{l})$.

\section{Discussion}

The mechanisms of the antidiuretic effect of carbamazepine is not clear. Ashton et al. [1] and Smith et al. [9] demonstrated in their patients a high concentration of arginine vasopressin in the plasma associated with carbamazepine-induced water intoxication. On the other hand Heim et al. [3] and Stephens et al. [11] observed a decrease in the level of plasma arginine vasopressin after administration of carbamazepine in healthy volunteers. They concluded that carbamazepine increases the sensitivity of the kidney to antidiuretic hormone in combination with a resetting of osmoreceptors. Our results, showing normal to low values in patients on carbamazepine monotherapy, are in agreement with this assumption. Furthermore, there was no correlation between the concentrations of plasma arginine vasopressin and carbamazepine levels in the serum. This finding confirms that there is no direct stimulating effect of carbamazepine, given in therapeutic doses, on the secretion of antidiuretic hormone in long-term treatment. It still remains possible that toxic levels of carbamazepine, which were absent in our series, could cause an increase in vasopressin production and consequently lead to water intoxication. Therefore, further studies on arginine vasopressin in toxic patients would be of interest.

In our patients treated with phenytoin, plasma arginine vasopressin was not reduced, in comparison with the other groups. Thus, chronic phenytoin administration seems not to have a direct effect on the posterior pituitary gland. This finding supports the hypothesis that the reversal by phenytoin of the antidiuretic effect of carbamazepine, seen in patients with combined therapy of both drugs, is caused only by a marked reduction of plasma carbamazepine concentrations during combined therapy with phenytoin [7].

Further studies of larger series of epileptics, with determinations of plasma osmolality and sodium, will show whether there is a definite lowering of arginine vasopressin levels under carbamazepine and primidone therapy compared to other anticonvulsants. 


\section{References}

1. Ashton MG, Ball SG, Thomas TH, Lee MR (1977) Water intoxication associated with carbamazepine treatment. Br Med J 1:1134-1135

2. Fichman MP, Kleeman CR, Bethune JE (1970) Inhibition of antidiuretic hormone secretion by diphenylhydantoin. Arch Neurol $22: 45-53$

3. Heim M, Conte-Devolx B, Bonnefoy M, Bouyard P (1979) Mesure du taux de la 8arginine vasopressine plasmatique par méthode de radioimmunologique chez la sujet normal, au cours d'und surcharge hydrique avant et pendent un traitement par carbamazépine. Pathol Biol (Paris) 27:95-98

4. Kimura T, Matsui K, Sato T, Yoshinaga K (1974) Mechanism of carbamazepine (Tegretol)induced antidiuresis: Evidence for release of antidiuretic hormone and impaired excretion of a water load. J Clin Endocrinol Metab 38:356-362

5. Marsland RL (1982) Carbamazepine. Neurotoxicity. In: Woodbury DM, Penry JK, Pippenger CE (eds) Antiepileptic drugs, 2nd edn. Raven Press, New York, pp 521-531

6. Perucca E, Garratt A, Hebdige S, Richens A (1978) Water intoxication in epileptic patients receiving carbamazepine. J Neurol Neurosurg Psychiatry $41: 713-718$

7. Perucca E, Richens A (1980) Reversal by phenytoin of carbamazepine-induced water intoxication: a pharmacokinetic interaction. J Neurol Neurosurg Psychiatry $43: 540-545$

8. Rascher W, Weidmann E, Gross F (1981) Vasopressin in the plasma of stroke-prone spontaneously hypertensive rats. Clin Sci $61: 295-298$

9. Smith NJ, Espir MLE, Baylis PH (1977) Raised plasma arginine vasopressin concentration in carbamazepine-induced water intoxication. Br Med J 2:804

10. Sordillo P, Sagransky DM, Mercado R, Micheln MF (1978) Carbamazepine-induced syndrome of inappropriate antidiuretic hormone secretion. Reversal of concomitant phenytoin therapy. Arch Intern Med 138:299-301

11. Stephens WP, Coe JY, Baylis PH (1978) Plasma arginine vasopressin concentrations and antidiuretic action of carbamazepine. Br Med J 1:1445-1447

12. Stephens WP, Espir MLE, Tattersall RB, Quinn NP, Gladwell SRF, Galbreith AW, Reynolds EH (1977) Water intoxication due to carbamazepine. Br Med J 1:754-755

13. Thomas TH, Ball SG, Wales JK, Lee MR (1979) Effect of carbamazepine on plasma and urine arginine-vasopressin. Clin Sci Mol Med 54:419-424 